\title{
Hardwood Planting in Ontario
}

\section{F. W. von Althen}

Department of Fisheries and the Environment Canadian Forestry Service

Great Lakes Forest Research Centre

Sault Ste. Marie, Ontario

P6A 5M7

\begin{abstract}
Most hardwood species can be planted successfully but plantation establishment is generally more difficult and more expensive for hardwoods than for conifers. For satisfactory growth most upland hardwood species demand a deep, fertile, moist but well drained soil. Intensive weed control during the early years after planting is an absolute necessity. Fertilization at time of planting has generally failed to promote seedling growth. Protection from girdling by mice and browsing by rabbits may be necessary during the early years after planting.
\end{abstract}

\section{Résumé}

On peut planter avec succès la plupart des essences feuillues mais l'établissement d'une plantation est habituellement plus difficile et plus dispendieux par rapport aux résineux. La plupart des essences feuillues des hautes terres exigent un sol profond, fertile, humide et bien drainé pour croître de facon satisfaisante. II faut donc absolument lutter intensivement contre les indésirables au cours des premières années qui suivent le plantage. En général, la fertilisation au moment du plantage n'accrût pas la croissance des semis. II sera peut-être nécessaire de protéger les semis contre l'annelage par les souris et le broutement des lapins pendant les premières années subséquentes au plantage.

\section{Introduction}

The earliest recorded hardwood plantings in Ontario were carried out around 1880 and consisted mainly of windbreaks or small plantations around farms and homesteads. Planting was intermittent until 1935 when planting stock production in the provincial nurseries was greatly increased. From 1935 to 1952 an average of 2 million hardwood seedlings and cuttings were planted annually. The failure of many plantations led to drastic curtailment of hardwood planting stock production in 1952, and few hardwood plantations were established during the next 13 years. Since 1965, interest in hardwood planting has increased again mainly because of a greater appreciation of environmental and aesthetic values, a scarcity of high quality hardwood trees for lumber and veneer, and in response to the loss of most elm (UImus spp.) trees to Dutch elm disease. Since 1965, 2 to 3 million hardwood seedlings, transplants, and cuttings have been produced annually (Anon. 1975). About half of the trees have been planted on private land and the rest on Crown land and in agreement forests (Table 1). Agreement forests are owned mainly by counties and conservation authorities but are managed by the Ontario Ministry of Natural Resources. Most of the trees have been planted on abandoned agricultural land, with the remainder planted in woodlots where poor harvesting practices or disease have resulted in the destruction of the original stand or where the introduction of new species appeared to be desirable.

Most hardwood species can be planted successfully, provided that the proper conditions are met. However, many hardwood species are very exacting in their climatic and site requirements and require intensive care and tending during the early years after planting. The cost of establishing a successful hardwood plantation is in the range of $\$ 150-200$ per acre $(\$ 370-490$ per ha) and therefore closely approaches the cost of raising an agricultural crop. Generally, it is also more expensive to establish a successful hardwood plantation than a coniferous plantation. This article discusses only the planting of upland hardwood species. Excluded are discussions of plantings of special stock such as large shade trees or hybrid poplars.

\section{Selection of the Planting Site}

The most important factor in establishing a hardwood plantation is the selection of a suitable planting site (von Althen 1964). For satisfactory establishment and growth, upland hardwood species demand a deep, fertile, moist, but well drained soil: even land that may produce fair farm crops is not always suited for good hardwood growth (Carman 1966). In southern Ontario, good hardwood sites will usually be found along creeks and streams, on lower slopes and in depressions where topsoil has accumulated, in abandoned orchards or gardens, and in agricultural fields where the $A$ and $B$ horizons are at least $45 \mathrm{~cm}$ thick. Hardwoods will never produce high quality timber when planted on dry, exposed slopes and ridges, or in areas where the topsoil is shallow and the subsoil consists of heavy, compacted clay.

Since sites for afforestation are generally available only because the land is unsuitable for agriculture, it would be unrealistic to envision the establishment of large hardwood plantations. At the same time, most available afforestation sites contain some small areas that are capable of growing high quality hardwood timber. These are the sites on which hardwoods should be planted.

\section{Site Preparation and Weed Control}

The second most important factor in successful hardwood plantation establishment and early growth of seedlings is the control of herbaceous competition. Since the effectiveness of weed control during the first few years after planting depends largely on the intensity of site preparation, the most intensively prepared sites will generally require the least post-planting weed control. 
Table 1. - Use of hardwood nursery stock in the year ending March 31, 1975

Species

Grown land and Education

Total

Number of trees planted

Silver maple.

260,518

290,944

4,250

555,712

(Acer saccharinum L.).

255,375

154,702

1,875

411,952

(Populus spp.).

138,125

208,150

2,650

348,925

Red oak.

86,671

116,564

550

203,785

(Quercus rubra L.). .

121,135

95,250

3,850

41,575

Cottonwood.

(Populus deltoides Bartr.)

Misc. species. .

Total.
49,203

$1,051,702$
60,019

48,150

133,375

45,500

219,919

$1,277,323$
4,175

400

185,329

143,800

137,225

87,100

25

10,400

24,325
Site preparation may take the form of plowing and disking or chemical eradication of the competing vegetation. The method used will depend on the condition of the soil; the topography, accessibility, density and composition of the existing cover; and the cost of the various methods under consideration. Under no circumstances, however, should the success of a plantation be jeopardized for an initial saving in the cost of site preparation and weed control.

Plowing and disking of the total plantation area is the best method of site preparation developed to date because it destroys all weeds, including the deep-rooted perennial species, loosens the soil and improves aeration and water infiltration, stimulates microbial activity, and incorporates plant material into the soil, thereby improving the nutrient availability and organic content of the soil.

Where plowing and disking of the total plantation area are not feasible or desirable because the soil may be subject to erosion, or the planting site may be partially treed, strips at least 1.8 $\mathrm{m}$ wide may be prepared for planting by cultivation (plowing, disking, or rototilling) or with herbicides (von Althen 1976). However, site preparation in strips is generally less effective in promoting tree growth than is complete mechanical site preparation.

Hardwood seedlings should not be planted in the bottom of furrows, because the temporary relief from competition seldom compensates for loss of growth owing to the lower fertility of the subsoil, loss of the seedling's height advantage, and the increased danger of flooding and frost damage. Planting on individual small scalps prepared by either mechanical or chemical methods should also be avoided, because weed control in patches smaller than $1 \mathrm{~m}$ in diameter is generally insufficient to promote satisfactory seedling growth. Application of the correct dosages of herbicides in small patches is also very difficult and most hardwood seedlings are easily damaged by excessive dosages, whereas insufficient dosages will fail to control the weed competition.

Post-planting weed control for the first three years after planting is an absolute necessity for successful hardwood afforestation. Manual and mechanical methods of weed control have proven very successful, but the frequency of operations required for effective control makes these methods rather expensive (Bey et al. 1975). Herbicides offer a more economical control, but many hardwood species are highly susceptible to damage by the dosages necessary for effective control. For example, newly planted white ash (Fraxinus americana L.) seedlings may be damaged by a dosage of more than 2 pounds of active simazine per acre $(2.2 \mathrm{~kg} / \mathrm{ha})$, while the effective control of weeds may require the application of 3 or more pounds per acre $(3.4 \mathrm{~kg} / \mathrm{ha}$ or more $)$. Although many herbicides are currently available and new chemicals are marketed every year, simazine (e.g., Princep ${ }^{\circledR}$ ) remains one of the most useful and reliable herbicides in hardwood afforestation.

Each tree species has its own herbicide tolerance at any given physiological state (White 1967, Ticknov 1968, von Althen 1972). This tolerance is modified by the texture and moisture of the planting soil, climate, seedling age, time since establishment, and time and method of application. To provide the best possible weed control without causing seedling damage, all dosages must be carefully metered.

Quackgrass (Agropyron repens [L.] Beauv.) is one of the most competitive weeds. Its elimination by mechanical means generally requires several years of intensive cultivation. Recently the 


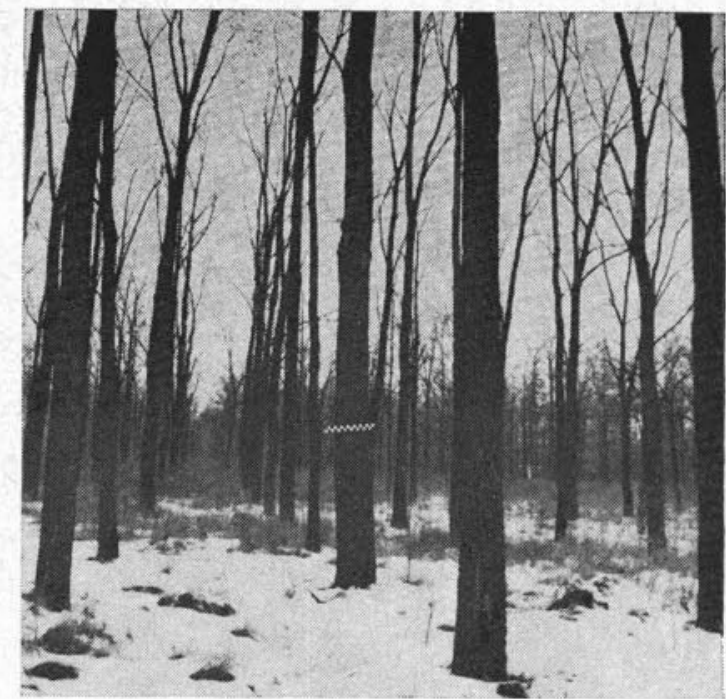

Fig. 1. Black walnut plantation, 38 years old, growing in a clay loam soil with an A + B horizon of $53 \mathrm{~cm}$. Avg. ht. $14.6 \mathrm{~m}$, avg. dbh $18.8 \mathrm{~cm}$.

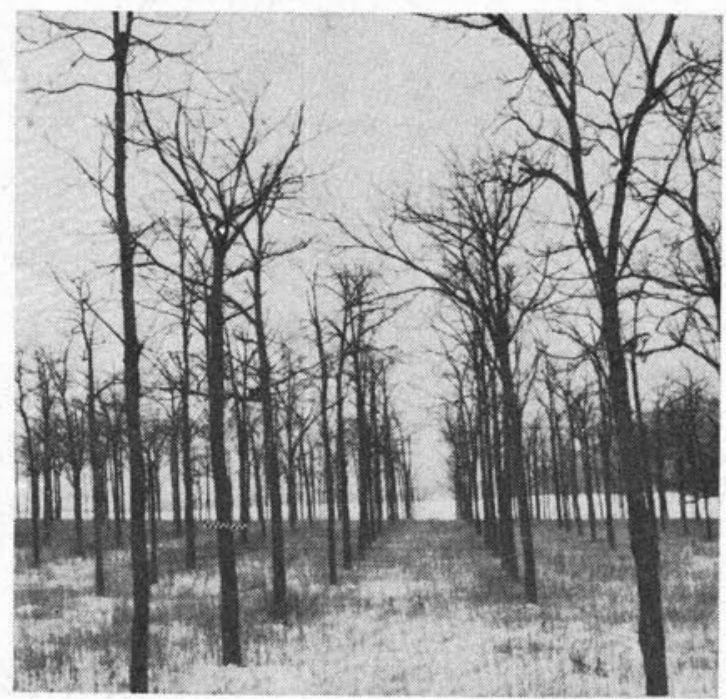

Fig. 2. Poor trees of the same plantation as in Figure 1 growing in a clay loam soil with an A + B horizon of 27 $\mathrm{cm}$. Av. ht. $7.3 \mathrm{~m}$, avg. dbh $11.8 \mathrm{~cm}$.

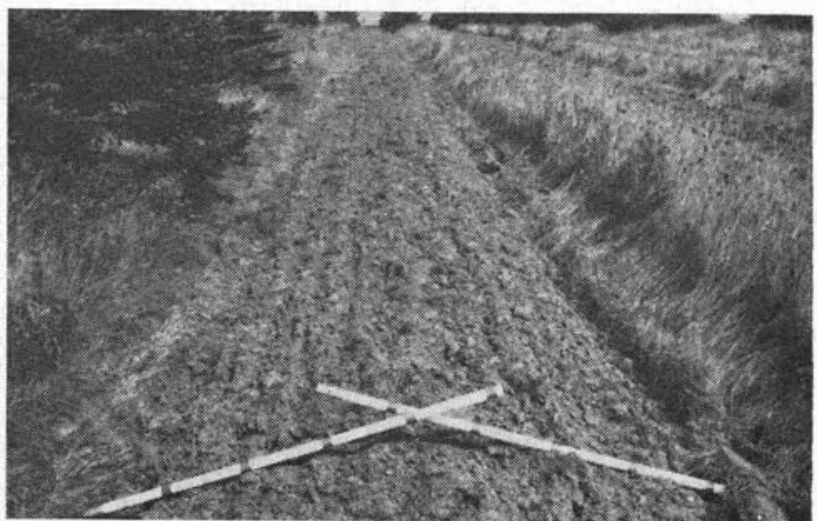

Fig. 3. Site preparation in strips, six furrows plowed from either side to the middle and disked.

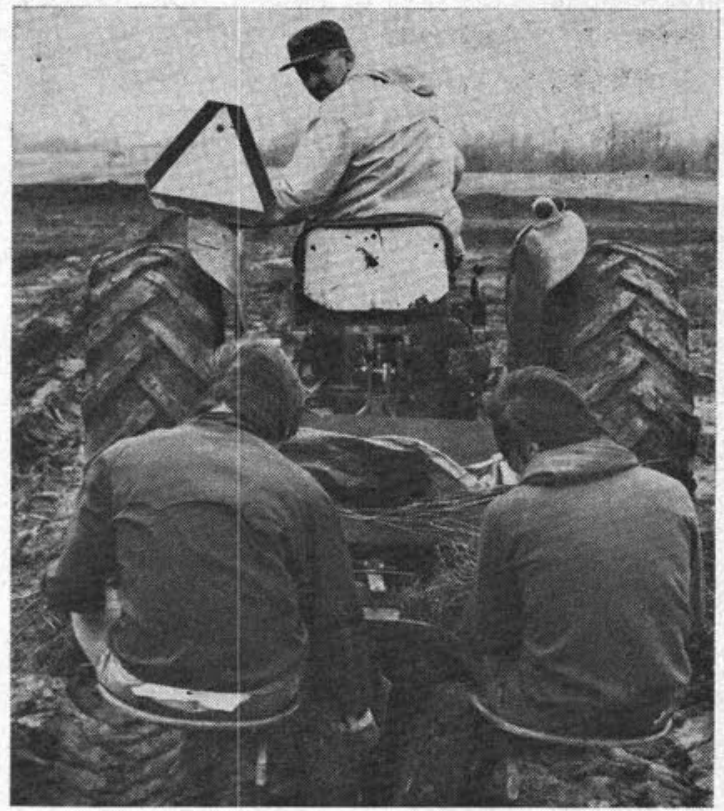

Fig. 4. Planting machine. Note unobstructed passage behind packing wheels which allows planting of tall seedlings.

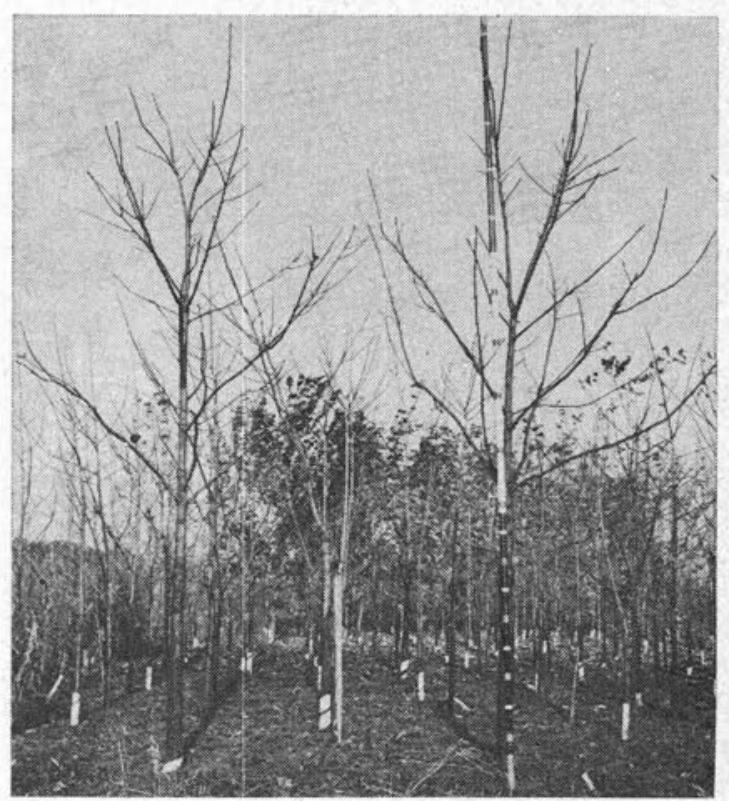

Fig. 5. Black walnut seedlings eight years after planting with weed control. Avg. ht. $2.6 \mathrm{~m}$.

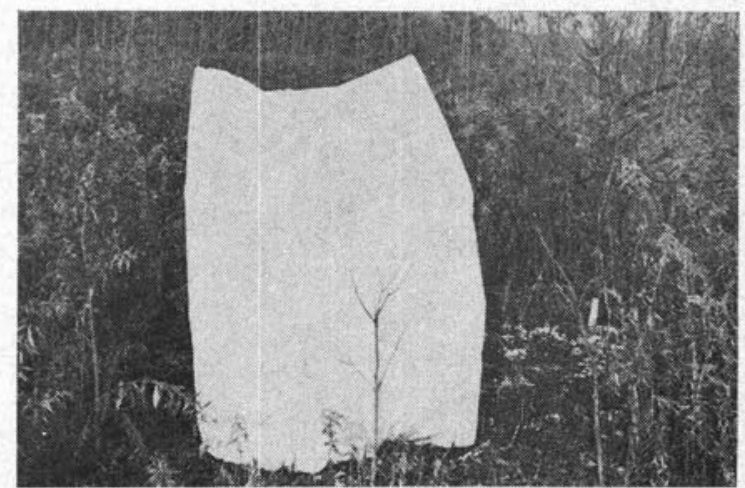

Fig. 6. Black walnut of same plantation as in Figure 5 but without weed control. Avg. ht. $1.2 \mathrm{~m}$. 


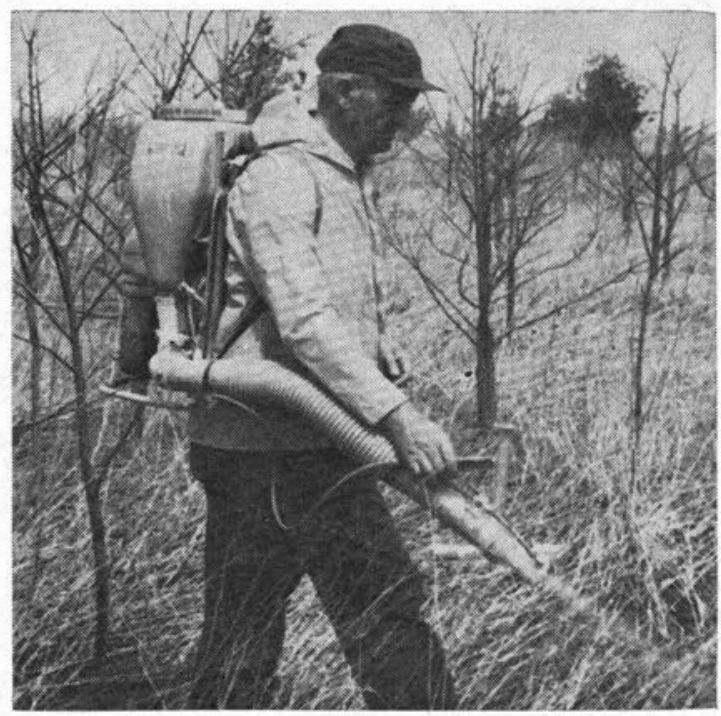

Fig. 7. Herbicide spraying with a motorized backpack sprayer.

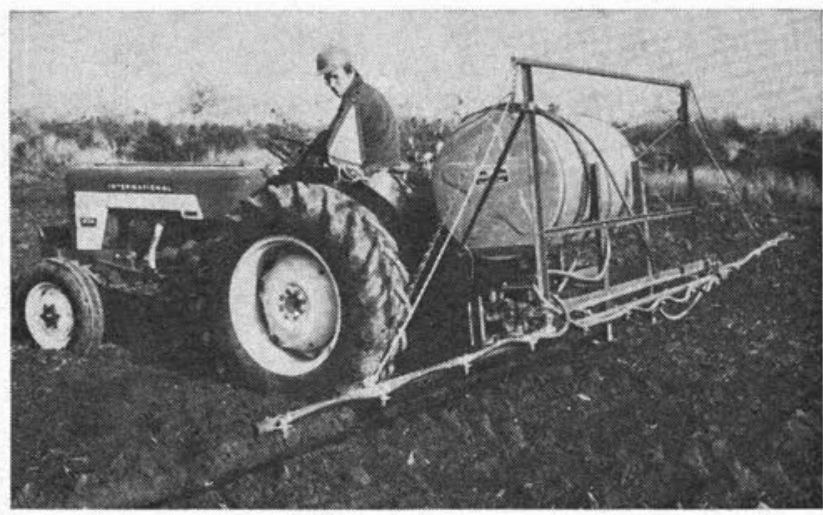

Fig. 8. Herbicide spraying with a tractor-mounted sprayer.

herbicide promanide (e.g., Kerb) has become commercially available. It effectively kills all grasses including quackgrass. Promanide is very specific to grasses, and when applied properly will kill grasses without harming trees or broad-leaved weeds. It may be broadcast over the trees, like simazine, without shielding or directing the spray away from the trees (Anon. 1970).

\section{Planting Stock}

The success of any plantation will also depend on the quality and suitability of the planting stock. Good planting stock should be sturdy and have a well branched root system (Limstrom 1963). Seedling size has been found to be more important than seedling age, with the diameter of the root collar being a good indicator of seedling size (Limstrom et al. 1955, Williams 1966). Forest managers have often expressed a preference for large transplant stock, believing that planting large trees would eliminate the need for site preparation and weed control. This probably is true for individual, large trees. However, when transplants $1 \mathrm{~m}$ high and up to 5 years old were planted in a

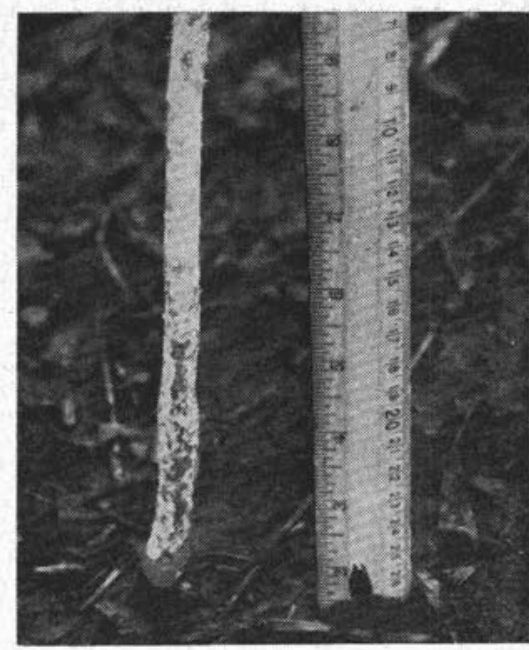

Fig. 9. White ash seedling girdled by mice.

weed-infested soil without prior site preparation or without subsequent weed control, they grew much more poorly than seedlings planted on the same site with site preparation and post-planting weed control (von Althen 1974). Because transplant stock is very expensive to produce, transport, and plant, and because the growth of all age classes of planting stock is generally inferior on unprepared sites to the growth of seedlings planted in plowed and disked soils treated with herbicides, it is much more economical to spend the available money on site preparation and weed control than on producing large transplant stock.

\section{Direct Seeding}

The advantages of direct seeding over the planting of nursery-grown stock are: (1) the development of a natural root system, which is especially important in species with pronounced tap roots such as the oaks (Quercus spp.) and black walnut (Juglans nigra L.), (2) elimination of planting injury, and (3) reduction of regeneration costs. The greatest disadvantage is the uncertainty of satisfactory establishment. Hardwood species with relatively small seeds such as ash (Fraxinus spp.) and birch (Betula spp.) were generally found to be unsuitable for direct seeding, while species with large seeds such as the oaks, black cherry (Prunus serotina L.), and black walnut showed some promise of success (Scholz 1964, Huntzinger 1967, Bjorkbom 1969, Russell 1971, 1975). Although little is known at present about the best method of direct seeding, it may have a place as a supplement to natural regeneration during poor seed years in strip and group shelterwood cuts. However, for the establishment of open field plantations the planting of nursey-grown seedlings at this time guarantees more consistent success than direct seeding.

\section{Planting Method}

Small hardwood seedlings may be planted either with a planting machine or by shovel using the wedge method. Large trees with spreading root 


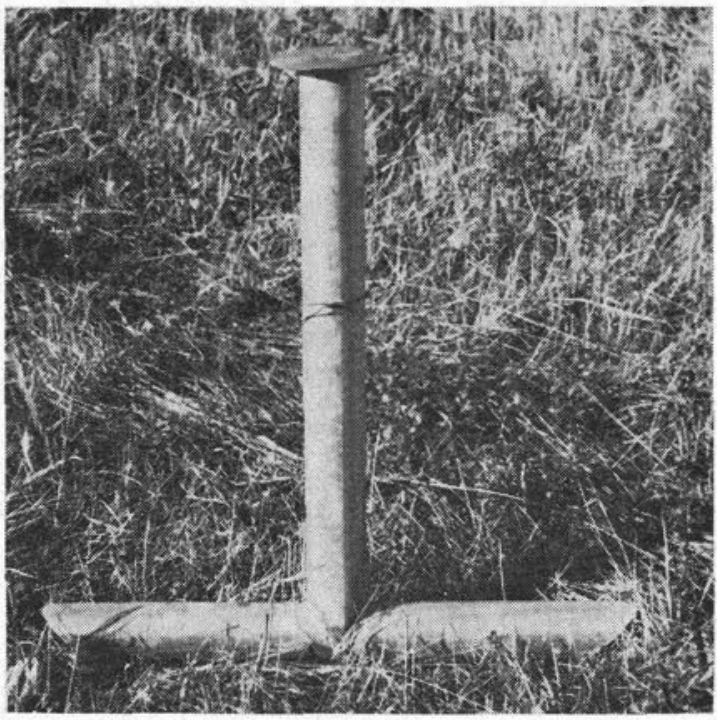

Fig. 10. Feeder station filled with poisoned grain.

systems are most efficiently planted in holes made with a post-hole auger. Care must be taken to plant the trees at the same depth as, or not more than $5 \mathrm{~cm}$ deeper than, they grew in the nursery and to pack the soil firmly around the roots. All trees should be planted in an upright position since leaning hardwood trees often develop a new vertical shoot from the root collar or along the stem. This necessitates the removal of the original stem by pruning, with the result that valuable height increment is lost (Erdman 1966).

\section{Spacing}

Little is known at this time about the best spacing for different species planted on a wide variety of sites. Until the results of spacing studies are available, a spacing of $10 \mathrm{ft}(3.2 \mathrm{~m})$ between rows and $5 \mathrm{ft}(1.6 \mathrm{~m})$ within rows is recommended. This spacing requires the planting of 870 trees per acre $(2,150$ per ha). It allows the passage of a medium-sized tractor between the rows for spraying or mechanical weed control; it promotes early canopy closure to shade out the competing vegetation; and it provides a sufficient number of trees for the selection of superior trees during thinnings.

\section{Fertilization}

Since low fertility is a common characteristic of land withdrawn from agriculture, fertilization appears to offer possibilities of improving tree growth on nutrient-deficient sites. Mitchell and Chandler (1939) showed that growth of established hardwood stands could be improved significantly by nitrogen fertilization. However, growth responses of hardwood seedlings to fertilization at time of planting have often been disappointing (Cummings 1941, McComb 1949, Burke and Williams 1973, Geyer 1974), probably for one or more of the following reasons: (1) the available soil nutrients may have been sufficient to satisfy the

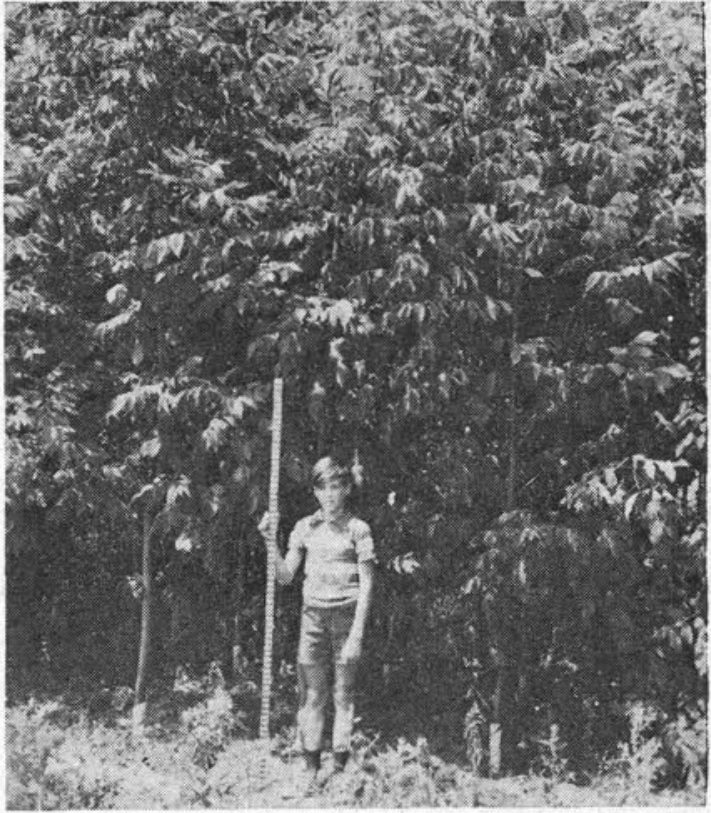

Fig. 11. Good white ash plantation six years after planting. Avg. ht. $4.3 \mathrm{~m}$.

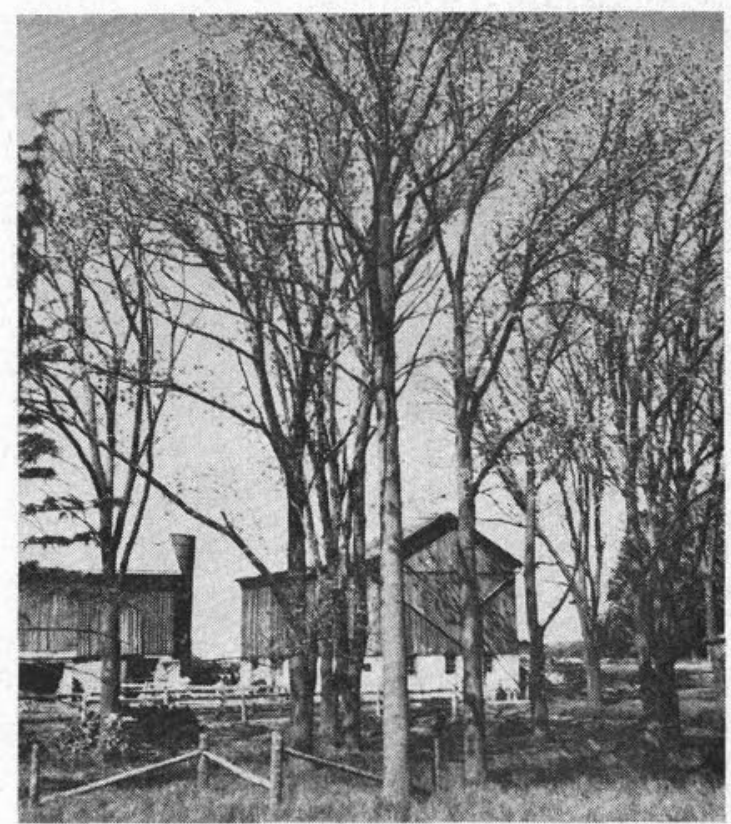

Fig. 12. Good walnut plantation 75 years after planting. Avg. ht. $24 \mathrm{~m}$, avg. dbh $51 \mathrm{~cm}$.

nutrient requirements of the newly planted seedlings, (2) the applied fertilizer either did not reach the roots or was not taken up by the seedlings, (3) the dosages of fertilizer applied were too small to produce measurable growth responses, (4) soil physical conditions, e.g., poor drainage, were limiting growth, and (5) a deficiency in nutrients, other than those applied, was more limiting to seedling growth than was the deficiency in applied nutrients (Auchmoody and Filip 1973, von Althen 1975).

Until more information is available, fertilization at the time of planting is inadvisable because it 
may do more harm than good by increasing weed competition. Fertilization is also expensive: money spent on fertilizer applications at the time of planting could be put to better use by intensifying site preparation and weed control treatments which have proven beneficial to seedling establishment and growth.

\section{Rodent Control}

Tree girdling by mice and browsing by rabbits can cause serious damage in hardwood plantations (von Althen 1971). The most common method of mouse control has been the broadcast application of poisoned grain. However, this method generally provides only short-term relief and is environmentally undesirable because of possible adverse effects on other fauna. Recently, experiments with poison grain feeder stations have provided longer lasting control and better safeguards (Radvanyi 1974) but before this method can be fully recommended, further refinement is required. Control of rabbit browsing may be obtained by painting repellents on the trees. However, this is rather expensive for the degree of protection afforded. The best protection against rodent damage is the elimination of vegetation; this deprives the animals of shelter and food and makes the plantation a hostile environment for rodent survival and reproduction. Also, elimination of weed competition generally increases growth, and fast growing trees are less vulnerable to rodent damage because they soon outgrow the danger.

\section{Summary}

Most hardwood species can be planted successfully but plantation establishment is generally more difficult and more expensive than the establishment of coniferous plantations. If money and manpower supplies are not assured to carry out the required work, hardwood planting should not be attempted since it will most likely result in poor tree growth or total plantation failure. However, on suitable sites, with the necessary care, hardwood plantations can produce a much higher return on investment than most coniferous plantations. Hardwood plantations also provide a favorable habitat for wildlife, and the aesthetic value of hardwood trees is well recognized.

\section{References}

Anon, 1970. Kerb selective experimental herbicide. Rohm and Haas Co. Tech. Bull. EX-A-141a.

Anon. 1975. Statistics 1975. Supplement to Annual Report. Ont. Min. Nat. Resour.

Auchmoody, L. S. and S. M. Filip. 1973. Forest fertilization in the eastern United States: hardwoods. p. 211-222 in For. Fert. Symp. Proc. USDA For. Serv., Gen. Tech. Rep. NE-3.
Bey, C. F., J. E. Krajicek, R. D. Williams and R. E. Phares. 1975. Weed control in hardwood plantations. p. 69-84 in J. S. Wright, Ed. Herbicides in Forestry For, Conf Proc. West Lafayette, Ind.

Bjorkbom, J. C. 1969. Seeding and planting birch. p. 79-82 in Birch Symp. Proc., USDA For. Serv., Northeastern For. Exp. Stn.

Burke, R. D. and R. D. Williams. 1973. Establishment and early culture of plantations. p. 35-41 in Black Walnut Symp. Proc., USDA For. Serv., North Central For. Exp. Stn.

Carmean, W. H. 1966. Soil and water requirements. p. 32-34 in Walnut Workshop Proc., USDA For. Serv. North Central For. Exp. Stn.

Cummings, W. H. 1941. Fertilizer trials for improved establishment of shortleaf pine, white ash and yellow poplar plantings on adverse sites. J. For. 39: 942-946.

Erdmann, G. G. 1966. Planting. p. 28-31 in Black Walnut Symp. Proc., USDA For. Serv., North Central For. Exp. Stn.

Geyer, W. A. 1974. Effects of weed control and fertilizer in establishing hardwood seedlings. Tree Plant. Notes 25:3-4.

Huntzinger, H. J. 1967. Seeding black cherry in regeneration cuttings. USDA For Serv., Northeastern For. Exp. Stn. Res. Note NE - 63 .

Limstrom, G. A. 1963. Forest planting practice in the Central States. USDA Agric. Handb. No. 247.

Limstrom, G. A., R. R. Finn and G. H. Deitschman. 1955. Planting stock grades for yellow poplar. J. For. 53(1): 2832.

McComb, L. A. 1949. Some fertilizer experiments with deciduous forest tree seedlings on several lowa soils. lowa State Coll. Agric. Mech. Arts Res. Bull. 369: 406-448.

Mitchell, H. L. and R. F. Chandler, Jr. 1939. The nitrogen nutrition and growth of certain deciduous trees of northeastern United States. Black Rock For. Bull. No. 11.

Radvanyi, A. 1974. Survey and control of small mammal populations on two hardwood plantations in southern Ontario. For. Chron. 50(5): 181-185.

Russell, T. E. 1971. Seeding and planting upland oaks. p. 4954 in Oak Symp. Proc., USDA For. Serv., Northeastern For. Exp. Stn.

Russell, T. E. 1975. Evaluation of animal hazards to spotseeded black cherry in central Tennessee. USDA For. Serv. Southern For. Exp. Stn. Res. Note 50-186.

Scholz, H. F. 1964. Seeding and planting tests of northern red oak in Wisconsin. USDA For. Serv., Lake States For. Exp. Stn. Res. Paper LS-7.

Ticknov, R. L. 1968. Tolerance of nursery plants to herbicides. Oregon Weed Control Handbook 1968: 141-155.

von Althen, F. W. 1964. Hardwood planting problems and possibilities in eastern Canada. Can. Dep. For. Publ. No. 1043.

von Althen, F. W. 1971. Mouse damage in an 8-year-old plantation. For. Chron. 47(3): 160-161.

von Althen, F. W. 1972. Preliminary guide to hardwood planting in southern Ontario. Can. For. Serv., Sault Ste. Marie, Ont. Inf. Rep. O-X-167.

von Althen, F. W. 1974. Planting trials with black walnut and white ash transplants in southern Ontario. Can. For. Serv., Sault Ste. Marie, Ont. Inf. Rep. O-X-190.

von Althen, F. W. 1975. Fertilization at time of planting fails to improve growth of hardwood seedlings. Can. For. Serv. Sault Ste. Marie, Ont. Report O-X-249.

von Althen, F. W. 1976. Effects of site preparation and post-planting weed control on the survival and height growth of planted hardwood seedlings. Can. For. Serv., Sault Ste. Marie. Ont. Report O-X-248.

White, D. P. 1967. Chemical control of weeds in new forest tree plantations. In Proc. 22nd North Central Weed Control Conf., Fargo, N.D.

Williams, R. D. 1966. Planting stock grades. p. 16-17 in Walnut Workshop Proc., USDA For. Serv., North Central For. Exp. Stn. 